\title{
Political Economy Diagnosis of Crude Oil Theft in Nigeria: The Way Forward
}

\author{
Omoyibo Kingsley Ufuoma, Ph.D \\ Associate Professor, Department of Sociology \& Anthropology, \\ Faculty of Social Sciences, University of Benin, Benin-city, Edo state, Nigeria \\ Email: ufuomaomoyibo@hotmail.com \\ Osunde Omoruyi \\ Lecturer, Department of Sociology \& Anthropology, \\ Faculty of Social Sciences, University of Benin, Benin-city, Edo state, Nigeria
}

\section{Doi:10.5901/mjss.2014.v5n2p297}

\begin{abstract}
Nigeria is said to be on the verge of a major fiscal crisis following unabated massive theft of crude oil in the Niger Delta. The Finance Minister (Mrs. Okonjo-Iweala) has said that oil theft/illegal oil bunkering costs the federal government \$1 billion every month. Oil theft is perceived as a consequence of the state's incapacity to bring succour to the populace in the Niger Delta and their desperation to meet their necessities. An analysis of oil theft in the context of the political economy theory reveals that it is a consequence of government's exploitation of the Niger Deltans: the horrors brought about by oil exploration; the desperation of the Niger Deltans to change the social order; government's repression of Niger Delta agitations and economic scarcity experienced by the Niger Deltans. Oil theft is part of a continuum which started with mild agitations to protests, intense activism and disruption of oil production. Apart from some Niger Deltans, top government officials, MNC's staff, the navy, soldiers and the police are involved in illegal oil bunkering. To halt oil theft would require the government. MNCs, security officials and the Niger Deltans to act in synergy in curbing the trend.
\end{abstract}

Keywords: Bunkering, Crude oil Theft, Militants, MNC's, Political-Economy.

\section{Introduction}

"Nigeria is on the verge of a fiscal crisis following unabated massive theft of crude oil in the Niger Delta" (Ejiofor, 2012). As at 2003, the Nigerian Economic Summit Group (NESG) estimated a daily theft of about $\$ 2.8$ million (Ikelegbe, 2005:209). However, the Managing Director of Shell Petroleum Development Company (SPDC), Mutiu Sunmonu proclaimed recently that oil theft cost Nigeria about $\$ 6$ billion annual revenue (Okafor, 2013). In a reaction, the Joint Task Force (JTF) in the Niger Delta said that SPDC might have given false statistics to support its claim of increased theft of crude oil (Amurun, 2012). However the statistics given by the Finance Manager, Ngozi Okonjo-Iweala is that the Federal Government loses $\$ 1$ billion revenue every month to oil theft (Premium Times, 2012) which translates to two times the figure given by the SPDC Managing Director. Whatever the case, it is very likely that "illegal oil bunkering is conveniently the most profitable private business in present day Nigeria" (Garuba, 2010). And little wonder that the Managing Director of Chevron Nigeria, Jay Prior, observed that he had "run companies that have had less production than is being bunkered in Nigeria" (Watts, 2009).

Oil theft is premised on the constitutional provision that the ownership and control of all minerals and mineral oil, in, under and upon any lands, and of rivers, streams and water courses in Nigeria are vested in the Federal Government. While the term, "bunkering" is used to described the process of filling up a ship with oil (Garuba, 2010:11). However, the Niger Deltans or those who engage in oil theft do not perceive their actions as absolutely wrong, rather they view it as "taking albeit illegally, what naturally belongs to them but is appropriated by non-indigenes" (Ikelegbe, 2005). In specificity, Asari Dokubo the leader of the Niger Delta People's Volunteer Force (NDPVF) is said to regard bunkering as legitimate because the crude oil found in their land is their property Ibid. In all, Mustapha (2010: 171) notes that "illegal oil theft is a consequence of the State's incapacity to bring succour to the populace and the populace's desperation to meet their necessities and day to day survival". We shall evaluate the truth of Mustapha's (2010) proposition as we conduct a theoretical inspection into oil theft using the political economy theory. In addition, we shall look at the factors that have led to the incidence of crude oil theft from a historical perspective. Finally, the monograph will conclude with how to 
intensify efforts towards halting (if feasible) or curtailing crude oil theft in Nigeria.

\section{Crude Oil Theft in Nigeria: A Theoretical Perspective}

Although Marx was not an Economist, he was attracted to a number of positions taken by popular Political Economists David Ricardo and Adams Smith. For example, they posited that labour was the source of all wealth. This ultimately led Marx to his labour theory of value, in which he argued that the profit of the capitalist was based on the exploitation of the labourer. Marx was also affected by the Political Economist's depiction of the horrors of the capitalist system and the exploitation of the workers (Ritzer, 2012:24). The capitalists in the context of the Nigerian Oil Economy are the multinational corporations (MNC's) while the labourers in the context of our analysis are not those who are employed by the MNCs but the owners of the crude oil; those who have been living on the land where oil is explored. They have been terribly and immensely exploited by the MNCs. The Niger Deltans have cried over the years due to the exploitation done them by the duo of the oil companies and the Nigerian government. Apart from complaining that the government and the MNCs exploit what naturally belong to them, they also refuse to give back a substantial amount derived from the crude oil towards developing the Niger Delta region. Worse still, the government at a point in time was appropriating royalty - what is paid to you for mineral extracted from your soil - to itself, instead of paying it to the Niger Deltans (Igiebor et al, 1993:183). For example, Okonta (2005:207) rioted that "an estimated 200,000 barrels are piped out of Nembe daily and the inhabitants receive neither rents nor royalties. The anti-riot police are there to ensure that the arrangement remains in place". The political economy theory also depicted the horrors of the capitalist system. One major horror that the capitalist MNCs have brought about to the Niger Deltan is the degradation of their physical environment. Though this is not given so much analysis in this section, it suffices to point out the report of Amnesty International on Petroleum, Pollution and Poverty in the Niger Delta, released in June 2009, which grimly inventoried the massive environmental despoliation caused by 1.5 million tons of spilled oil. The report described the slick alliance of the international oil companies and the Nigerian state as a "human rights tragedy" (Watts, 2009). This horror and other forms of exploitation have brought about various of conflict of which crude oil theft is one, after all, proceeds from crude oil theft have always been used to organize armed conflicts against the government and MNCs. The Political Economists failed to see the inherent conflict between capitalists and labourers, and for this Marx was critical of them including their denial of the need for a radical change in the economic order (Ritzer, 2012:24).

In his book, 'a political economy of Africa, Ake (1981:2), a prominent African Political Economist posited a number of statements that can be useful in our analysis of the political and economic issues surrounding the incidence of oil theft in Nigeria. Let us see.

"Those who are economically privileged tend to be interested in preserving the existing social order; and those who are disadvantaged by the social order, particularly its distribution of wealth, have a strong interest in changing the social order, particularly its distribution of wealth".

The above postulate helps in revealing that the Nigerian government (and the major ethnic groups in Nigeria) plus the MNCs have benefited so much from the proceeds of crude oil and on the other hand, the Niger Deltans who due to marginalization have not benefited from the crude oil found in their land as they should desire a change in the status quo. Hitherto, they have embarked on protests, disruption of oil exploration, threats, kidnappings, et al. And presently, we can perceive that their resorting to massive crude oil theft is one way to show that they gravely want a change in the status quo.

"A society where a high degree of economic inequality exists must necessarily be repressive. The repression arises from the need to curb the inevitable demand of the have-nots for redistribution. We see here economic conditions not only setting the tone of politics but also defining the role of coercion in society".

In line with Ake's position, the Nigerian government has always repressed the have-nots (the Niger Deltans) in their attempt to coerce the government to give them a substantial share of the so called 'national cake' which they believe is largely baked by them. As Okonta (2005:205) puts it euphemistically, "when faced with well organized and determined opposition with popular grassroots support, government forces may decide to 'sanitize' troublesome sites and root out the 'subversive elements' disturbing the 'public peace'. For example, during the period the Niger Deltans engaged in non-violent protests, the Nigerian government brutally repressed the Ogoni movement and murdered its influential and charismatic leader, Ken Saro Wiwa in November, 1995 (Watts, 2009). These brutal repressions carried out 
by the government over the years have inevitably and ultimately led to oil theft, thus continuing the coercion that it a consequence of economic conditions.

"The morality and values of a society tend to support the preservation of the existing division of labour and distribution of wealth in that society. The autonomy of morality and social values is more apparent than real. Contemporary Western morality condemns theft, and we forget that theft as a moral value is something created and dependent on a particular economic condition. Where there is no scarcity and no private property, the idea of theft will not arise".

In a nutshell, we despair from the above proposition that oil theft is a consequence of material deprivation being experienced by the Niger Deltans, and for the problem to discontinue, scarcity of resources in the Niger Delta should also discontinue. If not, then we are justified to posit that oil theft in Nigeria will not only continue but might even exacerbate.

\section{Background of Crude Oil Theft in Nigeria}

On January 3, 1993, about 300,000 Ogoni people of Rivers State staged a mass but peaceful protest to vent their anger at the despoliation of their land through oil - production activities. Their complaint was that their land has been systematically destroyed by oil companies which in collusion with successive Nigerian governments, have been stealing their prized natural resource - crude oil - without the people getting commensurate compensations for their losses unproductive farmlands, polluted waters and general environmental degradation (Igiebor, 1993: 182). The protest described above was led by the charismatic Ogoni leader, Ken Saro Wiwa). However, Saro-Wiwa and his Ogoni counterparts were not the first to protest against oil exploration activities in the Niger Delta. In fact, as far back as 1966, Isaac Adaka Boro, an ljaw nationalist and leader of the Niger Delta Volunteer Service, engaged in a "twelve day revolution" (Watts, 2009). Oloibiri (where Isaac Boro hailed from) is an oil rich town, however it is now a wretched backwater, a sort of rural slum home to barely one thousand souls (as opposed to its previous population of 10,000). They have no running water, no electricity, no roads, and no functioning primary school, the creeks have been so heavily dredged, canalized, and political that traditional rural livelihoods have been eviscerated. A British Engineer once said that he had explored for oil in Venezuela and Kuwait, but "has never seen as oil-rich town as impoverished as Oloibiri" (Watts, 2009). The government has always responded to the cry of the MNCs by foiling or repressing protests by the Niger Deltans. While Isaac Boro was simply bottled-up, Ken Saro-Wiwa, on the other hand, and eight of his colleagues were "condemned to death without legal representations. Sani Abacha, backed by a small band of military officers, convinced themselves that executing them swiftly was the best way to resolve the Ogoni unrest "once and for all" and to make it clear to Nigerians and the world that the authoritarian regime was no weakling" (Premium Times, 2012). They we re sentenced to death on October 31, 1995 and executed on November 10, 1995 (Shell.com). The reasons for the agitations and their brutal and tragic effects over the years can be attributed to the struggle for who gets what, when and how with regards to oil, not just by the Niger Deltans but Nigerians as a whole. "The Northern hegemony", according to Ikelegbe (2005:214) "taking advantage of military dictatorship began a regime of near total appropriation of the region's oil resources through an intense centralization and concentration of power and resources in the federal government". He continues:

"By decrees, oil and gas became owner by the federal government and progressively, the region's entitlement by way of derivation based allocation declined from $50 \%$ to a more $1.5 \%$ in 1984 and later 3\% in 1999. Further, the region was marginalized and in fact neglected in the development efforts that followed massive oil revenues. The region by the 1990s was one of the least developed and poorest" (Italics added)

In decrying the distribution mechanism of oil revenues, Watts (2006) sincerely disclosed that it has "not been just", and that "there has been a process of radical fiscal centralism in which the oil producing states (composed of ethnic minorities) have lost and the non-oil producing ethnic majorities have gained - by fair means or foul". It has also been revealed that $85 \%$ of oil revenues accrue to $15 \%$ of the population and that $\$ 100$ billions of $\$ 400$ billion in revenues have simply gone 'missing' since 1970. The anti-corruption Chief Nubu Ribadu once claimed that in $2003,70 \%$ of the country's oil wealth was stolen or wasted (Watts, 2006). To the majority of Niger Deltans, all of the above factors are not just sufficient but necessary to trigger protests in all its forms. Besides, the absence of infrastructural development has propelled various forms of conflict over the decades. For example, it was said that "in the oil rich states of Bayelsa and Delta, there is one Doctor for every 150,000 inhabitants" (Watts, 2006). In an interview with the late Ken Saro-wiwa some years ago, he lamented that while states like Borno, Sokoto or Kebbi have "free education from primary through tertiary levels --- the Ogoni people cannot go to school, not even primary school: (Igiebor, 1993:185). 
Another major factor that has precipitated the various forms of agitation that has eventually led to crude oil theft in government's failure to protect communities in oil producing areas while providing security to the oil industry (Watts, 2006). In connection with the government's reaction to protests, Okonta (2005:205) presents an exhaustive revelations:

\begin{abstract}
'The victorious faction responds by dispatching to the 'volatile' region special forces equipped with rocket-propelled grenades, machine guns, tear gas, stun paraphernalia of modern warfare, including experts in psychological terror. Entire hamlets and villages are razed and some of the inhabitants murdered or mutilated. Even peaceful demonstration provoke harsh reaction. On November 20, 2004, seven men were killed and many more injured when they attempted to mount a demonstration at an oil rig operated by shell. More than 100 protesters had gathered on a barge near the rig and sent leaders to demand a meeting with oil officials to discuss languishing development projects. Instead, army troops appeared in boats and opened fire on the barge".
\end{abstract}

The above sketch from antiquity tells us why the agitation have always graduated from mild to aggressive forms from mild agitations in the 1970s widespread community based protests in the 1980s. Then, by the 1990s, the civil society was heavily mobilized for intense activism. Later ( a little over a decade ago) bean a regime of disrupting oil production via occupation and shutting of oil facilities, abduction of MNC staff, hijack and seizure of MNC helicopters and boats, stoppage of production, etcetera (Ikelegbe, 2005:215). Their objective for engaging in all of the above was clear. "If they do not benefit from the oil output, then they will stop the oil from being produced" Ibid. And since they have not actually benefited from the oil output as they desire, and have realized that they cannot stop oil production, they have resorted to oil theft or illegal oil bunkering in a bid to benefit from the oil output.

\title{
4. Crude Oil Theft: Actors, Actions and Inactions
}

Overtime, there have been accusations and counter-accusations about those involved in illegal oil bunkering in Nigeria. For example, Asari Dokubo (a militant leader in the Niger Delta) once said: "There is nothing wrong if I take the crude oil found in our land, refine it and sell to our people.... The real bunkerer are the federal government who has been stealing oil from ljaw land since 1958" (quoted in Ikelegbe, 2005:227). While some Niger Deltan like Asari Dokubo are self acclaimed oil bunkerers, many others who are not even Niger Deltans have been pointed as suspects of illegal oil bunkering. Before taking an exhaustive look at those suspected to have been caught in the act, we shall take a fleeting look at what illegal oil bunkering involves.

"Bunkering is the term used to describe the process of filling up a ship with oil" (Garuba, 2010:110. According to Human Rights Watch (2003:19), the bunkeres "tap directly into pipelines away from oil company facilities and connect from pipelines to barges that are hidden in small creeks with mangrove forest cover". Asuni (quoted in Garuba, 2010:11) reveals three types of illegal bunkering viz:

1. A minor and small-scale pilfering of condensate and petroleum product destined for the local market.

2. Direct hacking into pipelines or tapping with a hose from oil wellhead.

3. Excess lifting of crude oil beyond the licensed amount, using forged bills of lading.

In his description, Ikelegbe (2005:221) observed:

\begin{abstract}
"Crude oil is tapped from pipelines and terminals of the oil producing companies with advance technological equipments in the waterways, creeks, swamps and high seas. Plastic pipes are fixed top manifold points and intersection of several pipelines and crude oil is then pumped into barges. In some cases, ships are hooked to hoses that siphon crude from MNC facilities that may be several hundred meters away".
\end{abstract}

Without mincing words, we can say that only the locales cannot be involved in illegal oil bunkering. However, we must begin by pointing out as we all know that "militants, gangs and pirates" (Ikelegbe, 2005:227) from the Niger Delta are directly involved. Describing their involvement in the act, Rory Carrol, the African Correspondent of the Guardian of London wrote:

"Criminal gangs are siphoning so much crude oil from pipelines in the Niger Delta that they have started using tankers to spirit it away ... siphoning off such quantities amid a landscape of jungle and marsh, with thousands of creeks, requires sophisticated equipment and organization. To the dismay of the government and oil companies, the thieves have proved that they have this in abundance" (quoted in Okonta, 2005:204).

However, the Nigeria police and navy "are often fingered as accomplices" (Garuba, 2010:11). In fact, the Chief of Naval Staff, vice Admiral Dele Ezeoba, said some time ago "that he had established a system to monitor the activities of 
officers of the Nigerian navy to determine their involvement in oil theft" (Odiegwu, 2013). The Nigerian navy and other security forces deployed to maintain peace are settled with cash payments to ensure that military operations and patrol did not interfere with illegal bunkering activities as indicated by a report on illegal sale of crude oil (Mustapha, 2010:172). Apart from the militants, Wikileaks said that "politicians and military leaders.... Are responsible for the majority of oil thefts in Nigeria's crude oil rich Niger-Delta as saying: "The soldiers are deeply involved. There is so much bunkering activity that it taking place in the Niger Delta that the military is not involved in... Eighty percent of soldiers in the region own the best cars... these are people who did not own a motorcycle before coming to the Delta" (quoted in Garuba, 2010:12). When we look at the complexity involved in oil bunkering, it is palpable that it is well beyond the ability of local militants to handle. While Niger Delta youths may handle the local tapping and loading, international syndicates from Eastern Europe, Russia, Australia, Lebanon, the Netherlands and France (including new entrants like Fillipinos and Ghanaians) all play roles in financing, transporting, and laundering the money accruing from the business (Garuba, 2010:12). In verity, "impounded vessels used for illegal bunkering often mysteriously vanish from police custody to reinforced credence to rumours that high-ranking Nigerian official are involved in oil smuggling" ibid. Okonta (2005:204-205) claimed that "the thieves too are members of the governing elite... invariably senior political figures and military officers..." He also claimed that the oil executives are included in illegal bunkering because they know who the oil bunkerers are, saying that "they cannot move against them because they are all partners in the same dirty crime: plunder" Categorically, the sheer number of players involved in illegal bunkering reminds us of Igbinovia's (2003) presumption of "the criminal in all of us", or more explicitly, "the criminal in all those" involved in the act of oil theft.

\section{Conclusion and the Way Forward}

We acquiesce with a former head of OPEC who once described oil as the "Devil's excrement" (Watts, 2009) and add that it is also the Devil's urine and fart specifically in Nigeria. However, we cannot keep blaming the Devil for out evils with regards to the issue surrounding crude oil in Nigeria. Rather, we must point out pungently that oil theft has not helped to solve the problems of the Niger Deltans. Watts (2006) reveals that "civil violence among and between oil producing communities and the state security force is endemic. It is estimated that more than 1000 people die each year from oil related violence". Thus, we have some blame for the Niger Deltans for that "crude oil theft is a crime, we should not give excuse to people stealing crude oil in the name of resource control or agitations" (quoted in Kalu, 2009). And because it takes two to tango, we also heap blames on the Federal Government and the MNCs for responding carelessly and selfishly to Niger Delta agitations and allowing it to aggravate and generate to oil theft. In addition, it is a big shame that powerful Nigerians and security agents who supposed to play roles in thwarting crude oil theft are involved in it. We owe such unpatriotic Nigerians no thanks but profane words of reproof. Since casting blames will not solve the problem of crude oil theft in any ramification, we hereby make the following recommendations on the way forward:

- The federal government must proceed towards a speedy development of the Niger Delta region to pacify its inhabitants for the marginalization done them over the years. This can help to gradually 'heal their wounds' and move them to support the security agents in their quest to tackle illegal oil bunkering.

- The MNCs as part of their corporate social responsibility must make provisions for the Niger Deltans to ensure both human and economic development. They should stop the degradation of farmlands and waters in order not to deprive them of their source of livelihood. They should also proceed to clean up the mess they caused to the physical environment of Niger Delta areas.

- Since, "security agencies in the country have been accused of high level convenience with pirates and oil thieves" (Amadi, Undated), the government must hunt for and fish out those involved to punish them in order to deter others from conniving with oil thieves.

- As army leader once said that they stormed communities and "destroyed the refineries and their products" (quoted in Nwanosike, 2013). While we applaud their brave action in discovering those illegal refineries, we have no cause to thank them for destroying the products, for it is as economic waste. We suggest that the products should not be destroyed, rather they should be handed over to the appropriate authorities who will in turn make sure it yields economic gain.

- Aggrieved and marginazed Niger Deltans must note that two wrongs cannot make a right. "Most times these illegal activities lead to huge economic waste, environmental degradation and loss of lives within minutes" (Nwanosike, 2013). After all, those who steal oil do not use the proceeds to develop their local communities, but to sponsor armed conflicts in the region and for their personal aggrandizement all to the chargrin of many 
locals. Thus, can appeal should be mix to the 'local Niger Deltans' to assist security agents to tackle illegal oil bunkering.

\section{References}

Adeleye, S. (2011), "Wikileaks Names Atiku, Late Yar'adua as Top Oil Thieves" Retrieved from www.nairaland.com on March 28, 2013. Ake, C. (1981), A Political Economy of Africa Longman Group Ltd. Essex.

Amadi, M. (undated), "Nigeria Loses \#780bn yearly to illegal Oil Bunkering"Retrieved from www.theeconomy.com/news260html on 26 April, 2013.

Amurun, O. (2013), "Crude Oil Theft: Is Shell Lying" Retrieved from www.nigerdeltastandard.com on March 28, 2013.

Ejiofor, A. (2012), "Fiscal Crisis Looms as Oil Theft Ravages Niger Delta". Retrieved from www.thisdaylive.com on 28 March, 2013.

Garuba, D.S. (2010), Trans-Border Economic Crimes: Illegal Oil Bunkering and Economic Reforms in Nigeria Policy Brief Series, No. 15, October, Global Consortium on Security Transformation, Retrieved from www.securitytransformation.org/gc_publications.php Ipdf on 15 April, 2013.

Human Rights Watch (2013), The Warri Crisis: Fuelling Violence Lagos: Human Rights Watch. Available online at www.hrw.org.

Igbinovia P.E. (2003), The Criminal in All of Us: Whose Ox have we not taken? A Professional Inaugural Lecture, Benin City: University of Benin.

Igiebor, N. et a; (1993), "We will defend our oil with our Blood" in Idowu, L. and Oyinlola, A. (eds) Tell: Courage in Print Diamond Publications: Lagos.

Ikelegbe, A. (2005), "The Economy of Conflict in the Oil Rich Niger Delta Region of Nigeria" Nordic Journal of African Studies 14(2): 208-234.

Kalu, U. (2009), "Crude Oil Theft: the Bad and the Ugly, Retrieved from wwwbusinessworldng.com on 22 April, 2013.

Mustapha, M. (2010), "Corruption in Nigeria: Conceptual and Empirical Notes". Journal of Information Society and Justice, 3(2): 165175.

Nwanosike, S. (2013), "illegal Oil Bunkering Matters Arising" Retrieved from wwwthetinewsoline.com on 26 April, 2013.

Odiegwu, m. (2013), "Oil Theft: CNS Probes Involvement of officers, Ratings, 'Retrieved from www.punchng.com on March 28, 2013.

Okafor, C. (20130, 'Alison Madueke: Crude Oil Theft Still Hurting Nigeria's Economy". Retrieved from www.thisdaylive.com on March 28, 2013.

Okonta, 1, (2005): "Nigeria: Chronicle of a Dying State". Current History; May, Retrieved from www.brookings.edu o 15th April, 2013.

Premium Times, (2012), "Nigeria Loses @155bn Monday to Oil Theft, Others. "Retrieved from www.premiumtimesng.com on 22n April 2013.

Premium Times, (2012), "Abacha Memo Sanctions Killing of Ken Saro-Wiwa and Others". Retrieved from www.saharareporters.com on 22n April 2013.

Ritzer G. (2012), Sociological Theory. McGraw Hill: New York.

The Ogoni Issue: Ken Saro-Wiwa - Nigeria. "Retrieved from www.shell.com.ng on 26 April 2013.

Watts, M. (2006), "Empire of Oil: Capitalist Dispossession and the Scramble for Africa."Retrieved from www.oldweb.geo.berkely.edu /projectresources.pdf on 15 April, 2013.

Watts, M. (2009), "Crude Politics: Life and Death on the Nigerian Oil Fields. "Niger Delta Economics of Violence, Working Papers No. 25, Retrieved from www.oldweb.geo.berley.edu/projectresources.pdf on15th April, 2013. 